\title{
Armed Forces
}

A key feature of the modern state is its monopoly of the legitimate use of violence, with its military and police forces the main instruments (Pierson 1996; Cohen and Service 1978). Military institutions are therefore central to the constitution of the bureaucratic field. On the other hand, the idea of a 'cosmopolitan soldier' is more difficult to entertain. Their careers are premised on being prepared to violently defend or expand the ideals or strategic interests of particular states. Yet military personnel in many states undertake humanities studies, travel the world, and in leisure time may gain a broad appreciation of cultural diversity.

With the rise of the Indonesian nation-state, its Tentara Nasional Indonesia (TNI, Indonesian Armed Forces) has played an important but often controversial role in Indonesian politics. The heroes of the anti-colonial revolution established and built up TNI. During the period from 1959 to 1965 however, TNI extended its political influence to the point of becoming what Munir (2003:71) called an 'octopus institution'. Through the New Order period, TNI further extended its direct involvement in politics, through guaranteed seats in parliament and positions in local political structures, often abusing human rights in the process. ${ }^{1}$

Militarism on Java itself is not a new phenomenon, a fact illustrated by the role of violence in 'traditional' Javanese culture. The dagger (kris) stored, ever ready, behind the back, as well as the prevalence of violent episodes in the wayang, demonstrate that 'Javanese culture' is not just about politeness (Boon 1990). Central Java also has longstanding links with TNI, and in the early post-Soeharto years the rise of militant youth and 'terror' wings of groups such as Laskar Jihad and Gerakan Pemuda Ka'bah (GPK) threatened and sometimes carried out violence both locally and in regions such as Maluku. TNI was implicated in these events, with various army and

1 Jun Honna (2003) provides an important analysis of shifts in civil-military relations in 1990s Indonesia. 
ex-army officers suspected of coordinating provocateurs (Violence in Ambon 1999; Hefner 2001).

At the same time, calm and goodwill also presided in the city of Yogyakarta. Many groups were ambivalent towards TNI, and student and street-arts groups were active in anti-violence campaigns. By many accounts, the Sultan had successfully banned on-duty armed forces from entering the city centre. I rarely saw individuals or groups in official military or even police uniform, despite the regular presence of roving party political campaigners, some of whom were themselves led by men in quasi-military fatigues.

In the midst of changes in which the Reformasi movement had brought to a head attempts to expose and discredit large sections of TNI, Central Java remained home to a number of Jakarta-controlled military bases and training institutions. I will discuss music performances that took place at two of these. While musical dimensions of a modern nation-state's armed forces often consist of formal marching bands and high-precision processions (Bannister 2002), the examples in this chapter featured campursari and musik jalanan respectively.

\section{CAMPURSARI AT AN ARMY BATTALION}

A Tombo Sutris campursari performance was held to commemorate the thirty-sixth year of an Army Battalion. Over the research period, the orchestra performed on average three times a fortnight, always with a specific theme. I had first met the orchestra and its leader Yanto the previous year, and had on occasion performed with them. Regarding the event under discussion, I ran into some of the musicians at the Sultan's Palace for Yogya Heritage Week, when they invited me to perform with them the following evening. During the following afternoon the orchestra members gathered at their usual rehearsal space. After the Azan call to prayer, an army bus took us five kilometres north to the Army Battalion Base, although I did not know anything about our destination or the event theme until we reached the venue. The bus entered the army grounds from a side road, and the orchestra gathered in a spacious tent behind a large stage. A few of the eight young women singers were given final touches to their make-up and sat ready to perform. Tombo Sutris' Imam and two army personnel hauled in bags containing full army fatigues for the musicians, and after trying out different sizes and combinations we were fully fitted. A quick sound-check fol- 
lowed, then after a meal back at the tent it was time to begin the show.

Glaring spotlights facing outwards from the edge of the grounds illuminated the stage. In the dark, crowd numbers steadily built outwards in three directions. The orchestra began unannounced, and then after two high-tempo instrumentals the Imam halted the music to begin the official speeches. Two army officers spoke briefly, each emphasising the commitment of the Battalion and TNI to the community. Then the Imam spoke passionately, his early words tinged with criticism of army behaviour, but finally concluding by shouting 'Hidup TNI! Hidup Indonesia!' (Long live the Indonesian Army! Long live Indonesia!) a half-dozen times in an attempt to rouse the crowd.

The orchestra resumed with a few instrumental pieces, after which the two MCs stepped to the microphones and began introducing orchestra members, in the process imparting humorous takes on topical issues. First to be announced was Visnu, who sat back in dark sunglasses with his saxophone as the MC stated that he was a member of Gerakan Aceh Merdeka (GAM, Free Aceh Movement), soon adding that GAM actually stood for Gerakan Anak Mahasiswa (Junior Student Movement). Coincidentally the nametag on my fatigues read 'Japan', which the other MC called attention to but then turned back to the audience and announced that 'There is a spy among us tonight'. He added that I was a member of Interfet, calling attention to the Australian military involvement in the recent crisis in East Timor.

After telling a few more politically loaded jokes, the MCs introduced the female singers. Each was immaculately dressed and made-up, resembling high-class nightclub performers more than Javanists in traditionalist kain and kebaya. With the young women singing and acting out their parts, the songs became progressively more up-tempo and dangdut-inflected. Sections of the orchestra inserted syncopated and precise instrumental passages between vocals, such as that from the keyboardist who swung and swayed passionately as he swept through a series of synthesised flute refrains. By ten $\mathrm{pm}$, the audience numbered over 5,000 , with young men crowding toward centre stage, women and children off to the sides, and a smoky haze of others toward Kaliurang Road in the distance. As a girl of around nine years began singing at centre stage, a few and then more and more young children climbed from the side-supports, stomping their feet and filling the stage. Eventually an army authority, evidently feeling awkward at being called upon to control young children, was forced to shoo them down. 


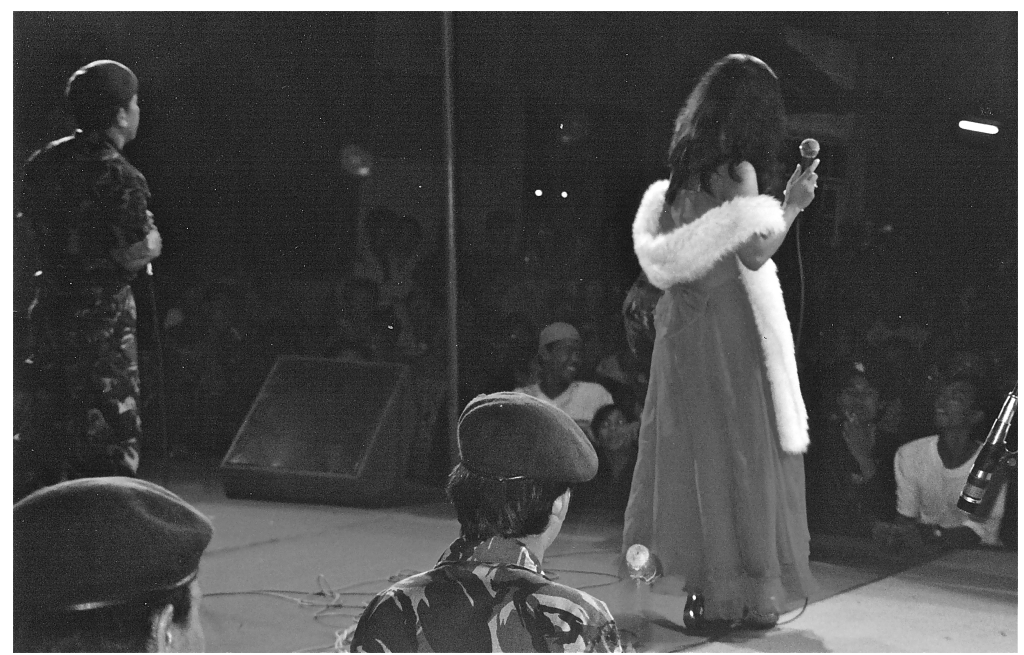

Tombo Sutris perform at an army battalion

Numerous guest appearances added variety to the evening. Three army officers sang dangdut and campursari-ised 1970s Indonesian pop songs. A comedy duo caused shrieks and hoots to ring across the audience. And the orchestra and singers inserted experimental sections into a number of their songs. The guest singers, comedians and MCs all enlivened the crowd, but the female singers produced the most animated response, especially among the younger men. The singers carefully gauged the sensuality of their actions and personas. Nevertheless, many older boys yelled out in the warbling tones of pubescent males, and a number of men in their mid-twenties rose to the stage. One shuffled slowly across the stage, smirking continuously in a self-contained 'other worlds' trance, deriving pleasure simply from being near the singers. Later in the evening, two other men rose from the audience and engaged in a kind of comedy caper, dancing slowly and sensually in front of the female singers but running out of reach when an army officer went to throw them off, only to move back to the middle of the stage each time the officer settled back.

After a song with a heavy rock beat, the show finished at midnight without speech or announcement. The crowd quickly dispersed, and backstage the musicians began changing back into their normal wear while Yanto, preman owner of the orchestra, talked with one of the main organizers, a soft-spoken com- 
mander of four battalions. The musicians were soon loaded back on to the bus and returned to their rehearsal space, where they sat about by the roadside for over an hour until Yanto returned with their pay.

This anniversary event for an army battalion in Yogyakarta exemplifies a military institution putting on a display of goodwill to the wider public. The audience included many residents from nearby neighbourhoods, army personnel and their associates and also, because the event took place near a main road, passers-by. As at the Tombo Sutris event at the Regional Parliament, the group (along with comedians and other entertainers) played a central role in fulfilling the organizers' aims of drawing a large audience and subjecting them to both entertainment and speeches. However, the two events differed in terms of the 'species of capital' involved. At the Regional Parliament, an underlying theme was the upcoming mayoral selections and the gathering of support among labour-based street workers. Power brokers at the Army Battalion performance, on the other hand, were concerned with displaying the cooperation of the Military and wider Indonesian society through the popular Javanist campursari. In terms of music and other performative aspects such as clothing and the overall program, there were some quite subtle differences between the two events. Most notable was the greater Islamic content at the Regional Parliament event, with the Army Battalion performance focussing more on secular endorsements of the state.

In addition to several people contesting various species of capital at such events, there was also some degree of grounded cosmopolitanism - an openness to and appreciation of otherness as viewed from home. As I have suggested, at one level military institutions and events might be seen as anathema to such an ethos. The main thrust on this occasion, it seems fair to say, was Javanist music and Islamic promotions with the aim of helping to restore the Military's reputation in wider society. Even the humour arguably did not lend itself to openness, with comedians and MCs making light of sensitive issues in Aceh, East Timor, and elsewhere. However, jokes at least gave air time to issues that would probably have been considered beyond discussion under the New Order government. And musically, the group's combinations of Javanist features with Islamic, western and other ornamentations could be said to be a model for cooperative relations between the centralised Armed Forces and the regions. Overall however, the military theme and setting meant that state interests dominated this performance. 
The National Air Force Academy ran a five-day 'Arts and Sports Festival' in their grounds on the outskirts of Yogyakarta. While commemorating the fifty-fourth anniversary of the Indonesian Armed Forces, such events also became contested terrain for statist capital, all the more so in the Reformasi period. Of interest on this occasion was the involvement of Malioboro street-arts leaders and street music groups. As mentioned earlier, while much of the music played on Yogyakarta's streets is of genres that underpin campursari (karawitan, langgam, kroncong, dangdut), musik jalanan is generally western-influenced folk-rock music with social and political commentary. TNI's incorporation of Yogyakartan street musicians for this event was, in other words, a meeting between the nation-state's prime bearer of the capital of physical force and local representatives of the underclass who were outspoken and influential on public opinion at street-level.

Amidst all the turmoil and change in state-society relations during this period, this festival promoted an image of stability and celebration through glossy flyers, public signs, and an opening parade that traversed the densely crowded Malioboro Street. The event was therefore brought to the attention of thousands, even if numbers that actually attended were barely in the hundreds. A number of street-arts leaders and Air Force cadets concurred that the festival was an attempt by the Air Force to help restore TNI's damaged reputation. A couple of Air Force officers, despite having access to state-legitimised forms of violence, were in competition over which of them had initiated the involvement of street musicians. And yet the greatest initiative arguably came from the street musicians themselves. In other words, both officers sought to be recognised as grounded cosmopolitans who could relate to the downtrodden on Yogyakarta's bustling, multicultural street. At the same time, the inclusion of street musicians was an admission that the latter wielded some influence over public opinion and, by extension, the bureaucratic field.

On the first morning, I arrived with a small group for whom the event and locale was something of a mystery. To enter the grounds from the northern side by the city's airport involved a several hundred metre drive along an isolated high-security road to a sentry gate. As we were to learn by the second day, a quiet back road entrance by a residential complex provided a much more relaxed route into the Academy. The festival took place just inside this lowkey, southern entrance. A row of temporary stalls was set up, lead- 
ing to another part of the Academy, which during the festival was a site for Air Force and skateboarding displays. Overwhelmingly however, activities centred on the elevated performance stage overlooking two basketball courts.

By seeking to promote TNI's status, and therefore its statist capital, the festival site, theme and agenda were clearly part of the bureaucratic field. While I often socialised with Tyas and other Malioboro Arts Community musicians, seeing them in the Academy grounds struck me as unusual, especially given their antiviolent stance. However, at least outwardly, their appearance and behaviour was quite relaxed. On the Air Force side, the air of rigid formality was something I had not seen outside of courtly rituals. A young officer named Rudi clearly had authority over the dozens of 18 to 21 year old cadets identifiable by their orange tracksuits. As he ambled along, each passing cadet would stop bolt upright and salute him with an intense rigidity. Rudi's unusually good command of English, and his culturally sensitive general knowledge was, I found, hard to reconcile with his position as a trainee fighter pilot. He represented state-legitimised violence but also demonstrated his reflexive and broad-ranging knowledge.

Clothing and hairstyles presented striking visual contrasts between the cadets and street musicians, which also extended to differences of posture, physique and even motor skills. One late morning before the start of the basketball games, a group of street musicians in ragged clothes and long and/or rarely tended hair played basketball at one end of the court. While their musicianship reflected their artistic facility, on the court they stumbled about, clumsily bouncing the ball with both hands, then hurling the ball toward the ring, often missing the backboard altogether. A team of cadets meanwhile stood on the sideline, struggling to contain their restlessness while awaiting the opportunity to warm up on the court. The cadets were not only all dressed the same; they all had virtually identical haircuts and were each around six feet tall with very upright postures. Music at the festival was to bring out a more animated side of the cadets, and friends and other attendees blurred the group boundaries, but overall these cadet/street musician distinctions were especially stark.

Holding the music competition on a stage overlooking the basketball games allowed spectators to simultaneously watch the games and the performances. But cheers and applause for the basketball players often drowned out the music, such that the musicians at these times commanded very little attention. At other times music took centre stage, especially when Academy members became involved toward the end of each day. On stage, eight musik jalanan 
groups played on each of the first three days, and these were then narrowed down to a half-dozen finalists. Put another way, a total of 24 groups played, six of them twice each. Malioboro Arts Community leaders selected the jalanan groups and, apart from some informal Air Force input, were the principal judges. The jalanan groups played two songs each. Their first on each occasion was a choice between an Ambonese song titled 'Sio mama' (My loving mum) and 'Kebyar-kebyar' (Glittering fireworks) by the late Indonesian country artist Gombloh. Each band was free to choose their second song.

The music carried many trademark jalanan features, including multiple acoustic guitars, vocal harmonies, snare drums played with brushes, kroncong ukuleles, and mellow saxophone. However, there was considerable variation both between bands and within them over time. An Ambonese commander newly appointed at the Academy had chosen 'Sio mama' as one of the street musician's prescribed choices. This directive reflected an exercise of state power, but was nonetheless astute in that it encouraged Yogyakartan street musicians to sympathise with a group that had become the enemy of some local youth groups.

The other option for musik jalanan groups, Gombloh's (Lockard 1998:89-90) 'Kebyar-kebyar', begins with the following lyric: 'Indonesia, the red of my blood, the white of my bones / United in your spirit / Indonesia, the beating of my heart, the throb of my pulse / United in your dreams'. ${ }^{2}$ This song, which received a number of treatments, promoted a sense of nationalism. On the early days, street groups played passionate but standard renditions, while by the finals they included extended Javanese-style atmospheric introductions with bells and shakers.

Songs of the groups' own choosing varied, especially in terms of their political messages. At the less obviously political end, groups played jazzed-up versions of songs such as Koes Plus' 'Buat apa susah' (What's the use of worrying?). Marthin, a young man from Flores, led the band that eventually won the competition. His group performed their original composition, 'Pesta dansa' (Dance party), which blended Indonesian and Pacific rhythms and harmonies. Other songs contained overt political commentary related to New Order-era contests over statist capital. One group played Bram Kampungan's 'Bung Karno', the original of which features a recorded speech delivered in 1964 by the then President Soekarno on Remembrance Day for the prophet Muhammad. Jimi Do-Re-Mi

2 Indonesia, merah darahku, putih tulangku / Bersatu dalam semangatmu / Indonesia, debar jantungku, getar nadiku / Berbaur dalam angan-anganmu. 
played an original composition in which he both referred to wellknown Japanese popular-culture characters and implored listeners to avoid conflict during the economic crisis. Another group built on a children's nursery rhyme to sing, in harmony, of the greediest children of the 'fat, deceitful king', this being Soeharto (Richter 2006).

Along with the street musicians' performances of popular, ethnic, and political songs, some days finished with a jam session. On the first day for example, the dozen musicians included Malioboro Streetside Singers, street group contestants and me. The jam finished with 'Bento', a jalanan anthem by Swami that criticises the greed of ex-Defence Minister Benny Moerdani and President Soeharto, and means 'stupid' in Javanese. But despite the many protest songs, the line between oppositional street musicians and obedient members of a violent arm of the state was not always sharp. For example, some street bands, including those who sang songs with anti-government messages, prefaced their performances with polite well wishes for TNI.

On the Air Force side, many of the cadets danced in joged style to the jalanan songs, thereby to some extent endorsing the performers' attitudes and messages. And at the close of the jam-session group's version of 'Bento', a senior Air Force fighter rose to the stage to sing. Dressed in full fatigues, red beret, and with weapons at his belt, the fighter motioned for the band to play the evergreen dangdut hit 'Kopi dangdut'. Cadets hooted with delight, a number of them stepping to the foot of the stage to dance in the joged style.

Non-jalanan associates of the street musicians, such as a newly formed funk band, also performed over the course of the festival. And Air Force members also gave a number of performances. A group of paratroopers enacted a coordinated gymnastic dance to

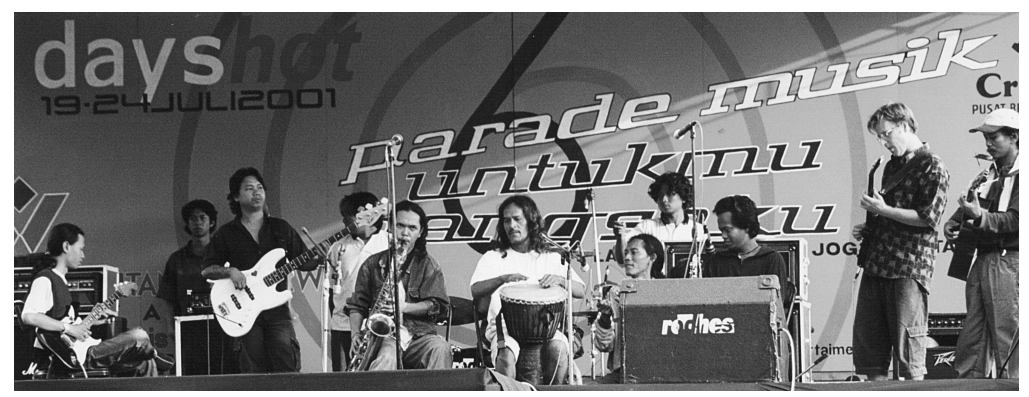

The author performs with KPJM and friends at the Air Force Academy 
the recorded music of American boy band NSYNC. In contrast to their deadly function, the paratroopers' movements were nimble and delicate, and their uniforms were shiny and immaculately pressed. The Academy also had their own rock bands, one of which pounced and growled around the stage performing songs by US metal-rap group Limp Bizkit. These bands won the approval of many jalanan musicians.

A ten-member all-female Gadjah Mada-based dance troupe gave the only female performance in the five days, and thus brought out notable gender and class differences between the university students, street musicians and Air Force cadets. Performances analysed throughout this book provide one means of mapping out female/male interactions in this context. Street musicians may for the most part have lacked formal education, but they also tended not to become outwardly sexualised around performances involving women. At the other end of the scale, many rural-oriented (kampungan) youth became highly animated when viewing female performers, although as discussed earlier the extent to which such dancing was sexually driven was often difficult to gauge. In terms of sexualised engagement, the cadets seemed to fall in between the street musicians and the kampung youth: even in their slight movements, the cadets visibly engaged with the dancers, yet discipline demanded that they act with decorum.

Related variations were evident in the case of females. The university dance troupe performed sensually, but kept this within limits, whereas the dangdut singers who became salacious were largely 'kampung' girls. Professional performers such as Yayi and Vivin discussed in relation to musical sexualisation, whose performance skills could not only rouse males but also to a considerable extent control their behaviours, fell somewhere between the two. Interestingly, female/male audience ratios tended to be most even in neighbourhoods, where animated and often sexualised physicalisations were greatest. However, male street musicians and female university students were most adept at performing in arenas associated with the Armed Forces. This, I suggest, demonstrates the tensions between bureaucratic and cosmopolitan practices that street musicians and university students straddled in such public activities.

Promoting street musicians gave the Air Force some credibility in its relations with 'the people', and conversely the Air Force Academy to some extent endorsed the street musicians. But audience numbers at the festival rarely reached a hundred in a city of half a million. On the Malioboro Community side, the venture succeeded in securing the assistance of the Air Force in removing 
accumulated litter and debris from Malioboro Street the following weekend. To some degree, this public display of cooperation must also have helped to legitimise TNI as capable of playing a positive role in the community beyond the exercise of physical force. Musically there was considerable cooperation between the two groups, but there were also underlying tensions. This is particularly evident given that any arm of the military is legitimate to the extent that it has a monopoly on violence, and because many of the street musicians' songs had anti-New Order/TNI themes. In this context, cadets playing Limp Bizkit and the street musicians singing protest songs arguably masked over tensions and reflected the pragmatics of their relationship.

These two military institution events demonstrate the roles of popular music in the bureaucratic field in early post-Soeharto Yogyakarta. First, organizers and performers treated the musical component of the army battalion event as an attempt to present an image of a centralised military in harmony with Javanism, and to an extent Islam, through the use of campursari music, comedians, and sexualised female singers. The longer, and in a sense, more complicated Air Force musik jalanan event requires some reflection. Here much of the music was openly oppositional and ethnically diverse, but the event was nonetheless a tool for an agent of the centralised state to gain local-level acceptance. Again, official bearers of the capital of physical force sought public cooperation with street workers to gain symbolic capital. In these ways, Bourdieu's conception of bureaucratic field helps to explain how power brokers use music to build public support and negotiate conversions of different species of state-related capital.

While Bourdieu's theory therefore helps us to identify forms of political contestation that may otherwise be hidden, taking music rather than power as a starting point broadens the analytical parameters. Throughout the festival, and especially at the end of each day, the formality of the cadets and the surrounds did not intimidate the street musicians, who lounged about much as they do in their everyday environs. Their attitudes and presentations ranged from offering deferential good wishes to TNI to performing protest songs from the Soeharto and early post-Soeharto periods. But in all cases this antimilitant group were being broadly supportive of TNI. On the other hand, the cadets were highly disciplined, far more so than the junior soldiers at the Battalion event, even though they also danced and cheered with apparent abandon, especially when Air Force members were performing on stage. The main activity linking the groups was the performance of culturally diverse Indonesian musics. 
It would nonetheless be problematic to assert that TNI members were imbued with an ethos of being at ease with cultural diversity. While a focus on power and political contestation cannot entirely explain the more light-hearted elements of the event, the congenial reception of ethnically diverse and often anti-military performances cannot supplant the past practices of this state institution. These cast a long shadow over possibilities for a genuinely cosmopolitan openness to cultural difference. The capital of physical force at both TNI-organized events therefore renders problematic the idea that cosmopolitan practice can flourish in such contexts. Indeed, power brokers in both cases were able to attract people with cosmopolitan, culturally diverse musics, and to then use these as a smokescreen for their capital-gathering agendas. Yanto's localised understanding of music was spectacularly successful in this regard, in the Army Battalion as elsewhere. In the context of the TNI military commemorations, therefore, even apparently cosmopolitan behaviours were largely subsumed as species of capital within the bureaucratic field. In contrast to this, the following chapter considers music performance at universities, sites of the production of homogenising national ideologies, critiques of state power, and artistic and intellectual creativity. 